Chirurgia (2020) 115: 775-782

No. 6, November - December Copyright@ Celsius

http://dx.doi.org/10.21614/chirurgia.115.6.775

\title{
Use of Silver Nitrate Application as Mini-Invasive Treatment of Pilonidal Sinus Disease
}

\author{
Burhan Hakan Kanat ${ }^{*}$, Fatih Mehmet Yazar², Nizamettin Kutluer ${ }^{3}$, Özgen Arslan Solmaz ${ }^{3}$, Mehmet Bugra Bozan², \\ Ferhat Çay ${ }^{4}$, Erhan Eröz ${ }^{5}$, Atakan Saçli ${ }^{6}$
}

\author{
'Department of General Surgery, Faculty of Medicine, Malatya Turgut Özal University, Malatya,Turkey \\ 2Department of General Surgery, Faculty of Medicine, Kahramanmaras Sutcu Imam University, Kahramanmaras, Turkey \\ ${ }^{3}$ Health Sciences University, Elazig Fethi Sekin State Hospital, Elazig, Turkey \\ ${ }^{4}$ Department of General Surgery, Faculty of Medicine Balıkesir University, Balıkesir, Turkey \\ ${ }^{5}$ Department of General Surgery, Toyotasa Emergency Hospital, Sakarya, Turkey \\ ${ }^{6}$ Department of General Surgery, Iskenderun State Hospital, Hatay, Turkey
}

${ }^{*}$ Corresponding author:

Burhan Hakan Kanat, MD

Associate Professor of General Surgery

Department of General Surgery

Faculty of Medicine

Malatya Turgut Özal University

Malatya,Turkey

E-mail: burhankanat@hotmail.com

\section{Rezumat}

Utilizarea aplicării de nitrat de argint ca tratament minim invaziv al chisturilor pilonidale

Obiectiv: Investigarea ratei de vindecare şi a efectelor adverse ale aplicării de nitrat de argint în tratarea chisturilor pilonidale.

Metode: S-au analizat, în acest studiu retrospectiv, numărul de cavități pilonidale şi complicațiile apărute în tratamentul prin aplicare de nitrat de argint al chisturilor pilonidale sacro-coccigiene în perioada ianuarie 2015 - iulie 2018. S-au obținut date din înregistrările aferente intervențiilor chirurgicale, externării şi monitorizării în regim ambulatoriu. Au fost excluşi din studiu 11 pacienți cu fişe de spitalizare incomplete din 56 tratați cu creion de nitrat de argint. S-au înregistrat date demografice incluzând: vârsta, sexul, durata monitorizării, numărul de aplicări, numărul de chisturi vizate şi ratele recurentei şi complicatiilor. Rezultatele au fost exprimate sub formă de frecvențe, medii şi intervale numerice. Pentru evaluarea significanței s-au utilizat testele U Mann-Whitney şi $\chi^{2}$.

Rezultate:Vârsta medie a pacienților a fost de 24,3 $\pm 5,18$ (interval de vârste: 14-36) ani, cu recurență a afecțiunii la $4(8,9 \%)$ pacienți. $\mathrm{Au}$ dezvoltat complicații $10(22,2 \%)$ pacienți, complicații ce au inclus abcese, eritem şi necroză la $5(11,1 \%), 2(4,4 \%)$ şi, respectiv, $3(6,6 \%)$ pacienți. Rata recurentei a fost semnificativ mai ridicată la pacienții care au dezvoltat abcese în perioada de monitorizare 
$(p=0,001)$ decât la cei care nu le-au avut. $\mathrm{Nu}$ s-a identificat nicio corelație semnificativă statistic între rata recurenței şi numărul de chisturi sau de aplicări de nitrat de argint.

Concluzie: Morbiditatea redusă şi rata ridicată de vindecare obținute prin aplicarea de nitrat de argint vin în sprijinul utilizării aplicării de nitrat de argint ca tratament de conservare eficace al chisturilor pilonidale la anumiți pacienți.

Cuvinte cheie: terapie minim invazivă, chist pilonidal, nitrat de argint

\section{Abstract}

Objective:To investigate the cure rate and adverse effects of silver nitrate application for treatment of pilonidal sinus disease (PSD).

Methods: Number of sinus pit orifices, and complications with silver nitrate application and debridement for sacrococcygeal PSD between January 2015 and July 2018 were analyzed in this retrospective study. Data were obtained from surgical, discharge, and outpatient follow-up records. Among 56 patients who were treated with silver nitrate stick, 11 patients with incomplete hospital records were excluded from the study. Demographic data including age, gender, length of follow-up, number of silver nitrate applications, number of involved sinuses and recurrence and complication rates were recorded. Results were expressed as frequencies, means, and range of values. The Mann Whitney $U$ and chi square tests were used to evaluate significance.

Results: Mean age was $24.3 \pm 5.18$ (range, 14-36) years, and recurrence occurred in $4(8.9 \%)$ patients. Complications developed in $10(22.2 \%)$ patients and included abscess, erythema, and necrosis in $5(11.1 \%), 2(4.4 \%)$, and $3(6.6 \%)$ patients, respectively. The recurrence rate was significantly higher in patients who developed abscesses during the follow-up period $(p=0.001)$ than those who did not. There was no statistically significant correlation between the recurrence rate and number of sinuses or the number of silver nitrate applications.

Conclusion: Low morbidity and high healing rates achieved with silver nitrate provide support for this application as a feasible and effective conservative outpatient treatment for PSD in certain patients.

Key words: minimally invasive therapy, pilonidal sinus, silver nitrate

\section{Introduction}

Pilonidal sinus disease (PSD) is a cystic formation containing hair that develops after chronic infection in the intergluteal cleft and is usually observed in young males (1). The etiology of PSD has been the focus of a long-standing debate, and PSD is currently considered an acquired disease (2). Since its first definition by Anderson in 1847, various medical and surgical methods were described for the treatment of PSD; however, there is still no consensus on the most appropriate treatment (3), and each treatment method has its own advantages and disadvantages. The ideal treatment of PSD is one that is less painful, involves a shorter hospital stay, has lower complication and recurrence rates, and allows the patient to return immediately to work after treatment (4). Patients preferences and experience of the surgeon are important factors in determining the most appropriate method (5). However, there is still a need to develop more efficient treatment methods.

Several agents for use in chemical cauterization and as lytic agents were previously evaluated for removal of granulation tissue $(6,7)$. The most commonly used and investi- 
gated agents are liquid phenol and crystalline phenol (8-11). The most important advantage of such nonsurgical methods is avoidance of hospital stays with immediate return to work after intervention as general anesthesia is not required (9-11).

Silver nitrate is a lytic agent widely used in wound care products and dressings for management of difficult wounds (12,13). In several clinical conditions such as perianal fistula and sinus, silver nitrate was shown to accelerate wound healing by removing excessive granulation tissue that causes epithelial cell destruction and activates fibroblasts (14). Several studies also investigated the utility of silver nitrate for treatment of pilonidal cysts $(15,16)$.

The aim of this single-center study was to retrospectively evaluate patients treated with silver nitrate for PSD.

\section{Materials and Methods}

\section{Patients}

In this retrospective study, the medical records of 218 patients admitted with PSD to the general surgery outpatient clinic of our hospital between January 2015 and June 2018 were screened. The following data were retrieved from the electronic and archive records: surgical and discharge notes, and records of dressings in the outpatient clinic. A total of 56 patients with PSD who were identified by the medical records were contacted by telephone to confirm the use of silver nitrate stick application. A total of 11 patients ( 8 males and 3 females) were excluded from the study due to incomplete records or as they could not be contacted. Thus, 45 patients were included in the final analysis. Indications for non-surgical intervention were patient compliance with ambulatory treatment, pain and discharge without abscess (first administration) and uncomplicated PSD $(<3$ midline pit orifices).

Demographic data including age, gender, length of follow-up, number of administrations, number of involved sinuses, and recurrence and complication rates were recorded.

\section{Silver nitrate application}

All patients included in this study were asked to shave the sacrococcygeal region and intergluteal sulcus before each procedure. Under sterile conditions, patients were reexamined, and wounds were explored. Any sinus tracts were cleaned and debrided under local anesthesia through the sinus orifice. For patients with sinus pits too small for the silver nitrate stick to access, the sinus pits were expanded using a mosquito clamp ( $\mathrm{BH}-109$ Aesculap $^{\mathbb{}}$; Aescuplap Werke AG, Tutlingen, Germany) (Fig. 1A). In 32 patients with more than one sinus pit, the same approach was used for each sinus pit separately. At the

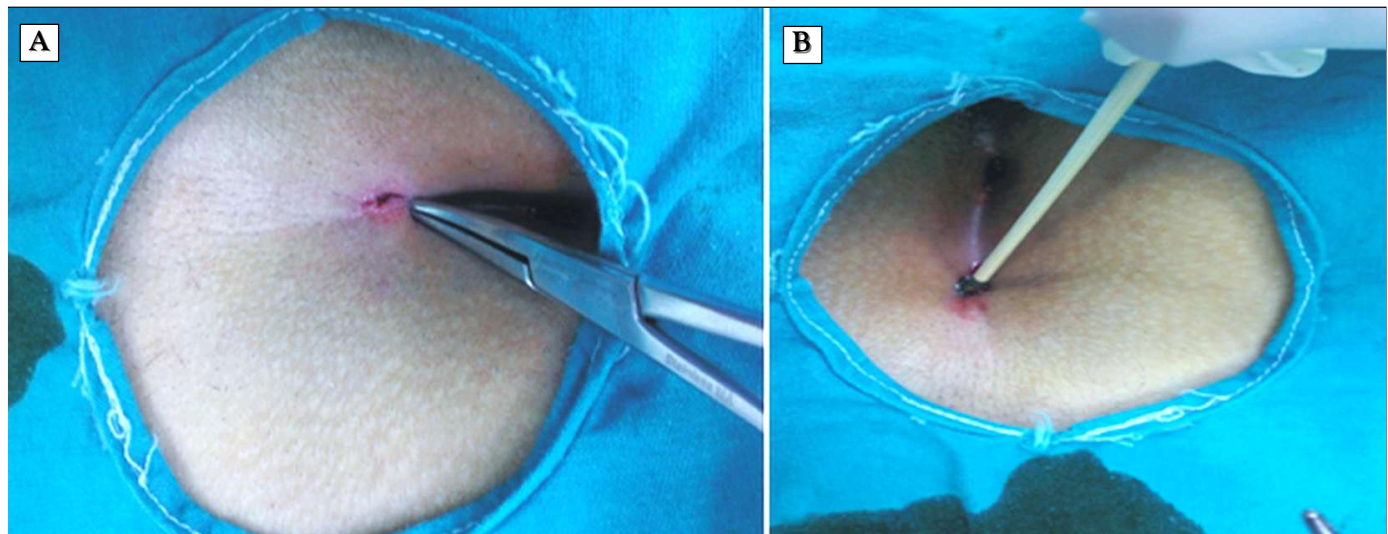

Figure 1. (A) Sinus orifice is expanded with a mosquito clamp, and content of the sinus tract including hair and debris is cleaned. (B) Silver nitrate is applied. 
beginning of the intervention, antibiotic cream containing nitrofurazone (Furaderm ${ }^{\circledR}$, Toprak Pharmaceuticals and Chemicals Co., Istanbul, Turkey) was applied to the surrounding skin tissue to prevent any irritant effects of the silver nitrate stick.

A silver nitrate stick (HemoStop ${ }^{\circledR}$ silver nitrate applicator-6 containing $75 \%$ silver nitrate and $25 \%$ potassium nitrate) was inserted into the tract (Fig. 1B). In patients with more than one sinus orifice, a separate stick was used for each sinus orifice. Precautions was taken in all applications for sticks not to make contact with sinus tract walls.

Patients were asked to return to work on the same day of the procedure. They were advised to refrain from bathing for 24 hours. Follow-up examination was conducted 48 hours after intervention, and any necrotic epithelium was cleaned and included removal of hair and necrotic tissue from the sinus orifice with a sterile clamp. After the first application of silver nitrate stick, debris containing necrotic epithelial cells and hair was cleaned and pathologically analyzed (Fig. 2 A, B). Hematoxylin and eosin-stained biopsy specimens were histopathologically evaluated with a light microscope by the same physician.

Patients who developed complications following the procedure, including those with late-onset complications were called for an immediate follow-up examination 14 days to assess the closure of sinus tracts and the presence of discharge. In patients with open sinus orifices at follow-up examination, the procedure was repeated at monthly intervals. A minimum of three and a maximum of five applications were performed in all patients included in this study. Patients with open sinus orifices, continuing discharge, and/or recurrent complications despite recovery from treatment at the end of the 12-month follow-up period were deemed unresponsive to treatment, and surgical treatment was recommended. Patients with completely closed sinus orifices and those with no complaints such as pain or discharge were considered as fully responsive to treatment (Fig. 3). Patients considered to be fully responsive to treatment were recommended for outpatient follow-up at 6-month intervals for the first year and annually thereafter.

Antibiotics were not prescribed after the procedure. In patients who developed infection and abscess of the sinus, the abscess was drained under local anesthesia, and $500 \mathrm{mg}$ cefuroxime sodium (Nobel Ltd, Istanbul, Turkey) was prescribed. If recurrence was seen during follow-up, surgical treatment was performed by the surgeon who originally treated the PSD.

\section{Statistical Analysis}

Statistical Package for Social Sciences [SPSS $^{\circledR}$ version 16.0; SPSS, Chicago, IL, USA] was used to analyze the data. Data were presented as frequencies, means \pm sd, and range of values, and the Mann Whitney $\mathrm{U}$ and chi-square tests were used. Pearson and Spearman correlation
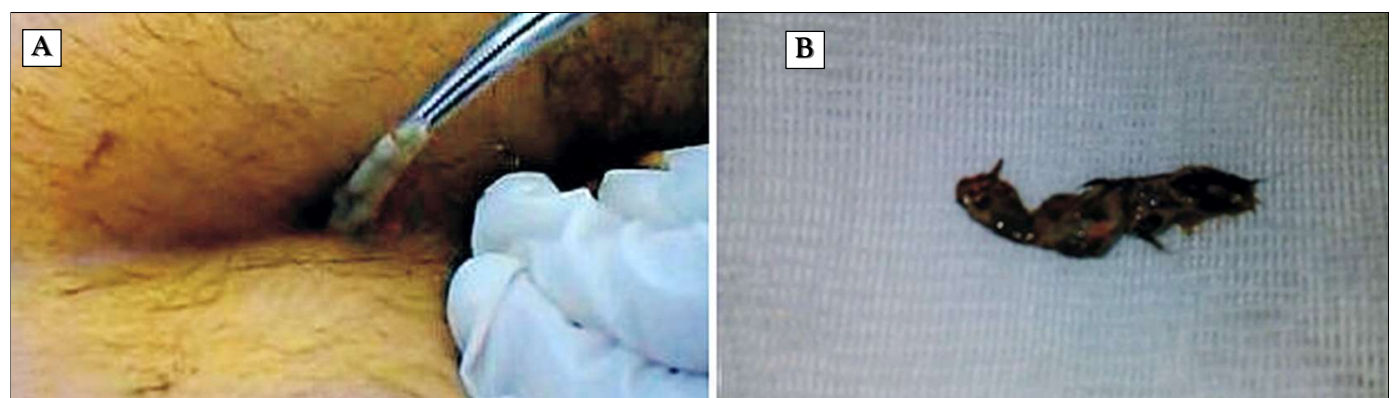

Figure 2. (A) 48 hours after application of silver nitrate, necrotic granulation tissue and hair are removed from the sinus tract. (B) Removed tissue. 


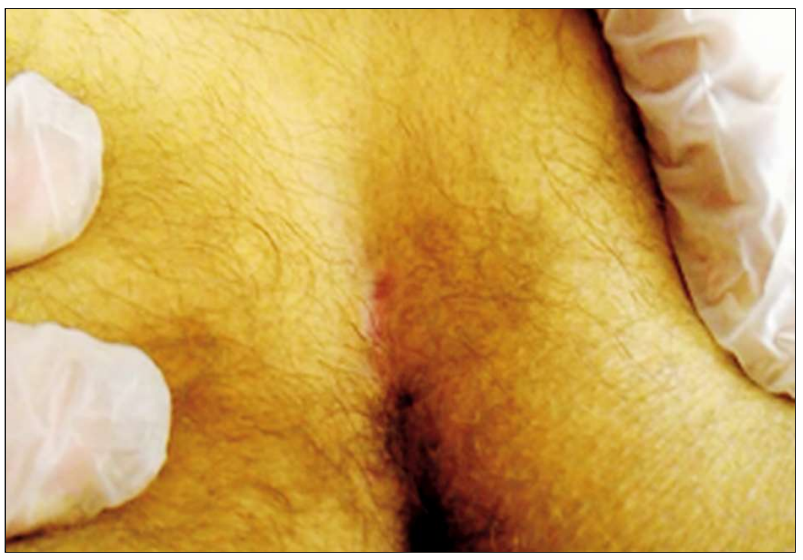

Figure 3. Appearance of healed sinus of a patient who received four applications of silver nitrate, seen at 32 months after last application.

analyses were used to determine the risk factors for complications and recurrence, $p$ values $<0.05$ considered statistically significant.

\section{Results}

Of a total of 45 patients included in the final analysis, 42 were males and 3 were females. Mean age of the entire cohort, males, and females were $24.3 \pm 5.18$ (range, 14-36), $24.2 \pm$ 0.8 (range, 14-36), and $26 \pm 1$ years (range, 25-28), respectively (Table 1). Mean follow-up period was $29.1 \pm 7.1$ (range, 14-43) months. In this study, $13(28.9 \%), 23(51.1 \%)$, and 9 (20\%) patients had 1,2 , and 3 midline sinus pits, respectively (Table 2).
Table 1. Demographic data of patients treated with silver nitrate application

\begin{tabular}{lrrr}
\hline & Male & Female & $\mathbf{P}$ \\
\hline $\mathrm{n}$ & $42(93.3 \%)$ & $3(6.7 \%)$ & \\
\hline Age (years) & $24.2 \pm 0.8$ & $26 \pm 1$ & 0.41 \\
\hline Mean number of procedures & $3.9 \pm 0.1$ & $3.7 \pm 0.3$ & 0.58 \\
\hline Recurrence $(\mathrm{n} / \%)$ & $4 / 42$ & $0 / 3$ & 0.58 \\
\hline Mean number of sinuses & $1.93 \pm 0.11$ & $1.67 \pm 0.33$ & 0.55 \\
\hline
\end{tabular}

Silver nitrate application was performed 3 , 4, and 5 times to $13(29 \%), 24(53 \%)$, and 8 (18\%) patients, respectively (Table 3). Briefly, none of the patients who received three " applications (0\%) developed complications, whereas complications arose in 6 (25\%) patients who received four silver nitrate applications. Conversely, four out of a total of eight patients $(50 \%)$ who required five silver nitrate applications suffered from complications.

Abscess developed in two, one, and two patients after one, two, and three or more silver nitrate applications, respectively. In all patients with abscess formation, drainage performed under local anesthesia followed with antibiotic treatment was successful in its resolution. In three patients who developed skin necrosis, the necrotic section was excised under local anesthesia as an outpatient procedure. Two patients who developed erythema received conservative therapy. Total recurrence was seen in 4 patients $(8.9 \%), 3$ of whom had developed abscess. The recurrence

Table 2. Relationship between sinus tract characteristics and the number of silver nitrate applications, complications, and recurrence

\begin{tabular}{|c|c|c|c|c|c|c|c|}
\hline & n & $\begin{array}{l}\text { Number of applications } \\
\quad \text { (mean } \pm \text { SD) }\end{array}$ & p & $\begin{array}{l}\text { Presence of } \\
\text { complications }\end{array}$ & p & Recurrence & p \\
\hline \multicolumn{8}{|c|}{ Number of sinus pit orifices } \\
\hline 1 & 13 & $3.38 \pm 0.18$ & & 0 & & 1 & \\
\hline 2 & 23 & $3.87 \pm 0.1$ & & 5 & & 1 & \\
\hline 3 & 9 & $4.67 \pm 0.17$ & 0.01 & 5 & 0.005 & 2 & 0.34 \\
\hline
\end{tabular}

Table 3. The relationship between the number of silver nitrate applications and complications

\begin{tabular}{lcccc}
\hline & $\mathbf{3}$ applications & $\mathbf{4}$ applications & $\mathbf{5}$ applications & $\mathbf{p}$ \\
\hline $\mathrm{N}$ & $13(28.9 \%)$ & $24(53.3 \%)$ & $8(17.8 \%)$ & \\
\hline Complication ratio & 0 & 6 & 4 & 0.007 \\
\hline Recurrence & 0 & 2 & 2 & 0.047
\end{tabular}


rate was significantly higher in patients with complications than in those who did not develop complications $(p=0.009)$ and in those patients who developed abscesses during the follow-up period $(\mathrm{p}=0.001)$. All recurrences developed within the first 11 months after silver nitrate treatment.

There was a statistically significant relationship between the development of abscess and recurrence $(\mathrm{r}: 0.635, \mathrm{p}<0.001)$. Additionally, the recurrence rate correlated with the number of sinuses $(r: 0.337, p<0.001)$, sinus tract length $(r: 0.143, p=0.045)$, and the number of silver nitrate applications. There was a correlation between the number of silver nitrate applications and complications $(\mathrm{r}: 0.239, \mathrm{p}=0.007)$ as well as recurrence ( $\mathrm{r}: 0.138, \mathrm{p}=0.047)$.

By histological evaluation, necrotic debris, neutrophil infiltration, fibrocollagenous connective tissue, and silver nitrate remnants were observed as indicators of chemical cauterization (Fig. 4A, B).

\section{Discussion}

The results of this study showed that more than $90 \%$ of the patients recovered clinically with treatment with silver nitrate. While recovery was not seen with single application in any patient, there was an increase in sinus tract length together with the increase in number of silver nitrate applications, leading to an increase in the complication rate. While no complications were seen in patients with single midline pit orifices, recurrence occurred in one patient with a single pit orifice. The male/female ration of $8.3 / 1$ was consistent with literature (17).

Silver nitrate, first used for PSD by Korb in 1951 (15), is suggested to exert its beneficial effects via several mechanisms. Studies showed that silver nitrate accelerated wound healing in diseases such as perianal fistula and sinus by removing excessive granulation tissue, which can precipitate epithelial cell destruction, via a lytic effect and by activating fibroblasts (14). Anti-inflammatory mechanisms of silver nitrate were also demonstrated (18). Additionally, the antibacterial effect of silver is proposed to contribute to rapid wound healing in chronic inflammatory events (14).

Silver nitrate treatment was applied to patients with 1-3 sinus orifices in the present study. We observed that there was a correlation between the number of sinus pit orifices and complication rates, number of silver nitrate applications, and recurrence (Table 2). As there are several surgical and conservative
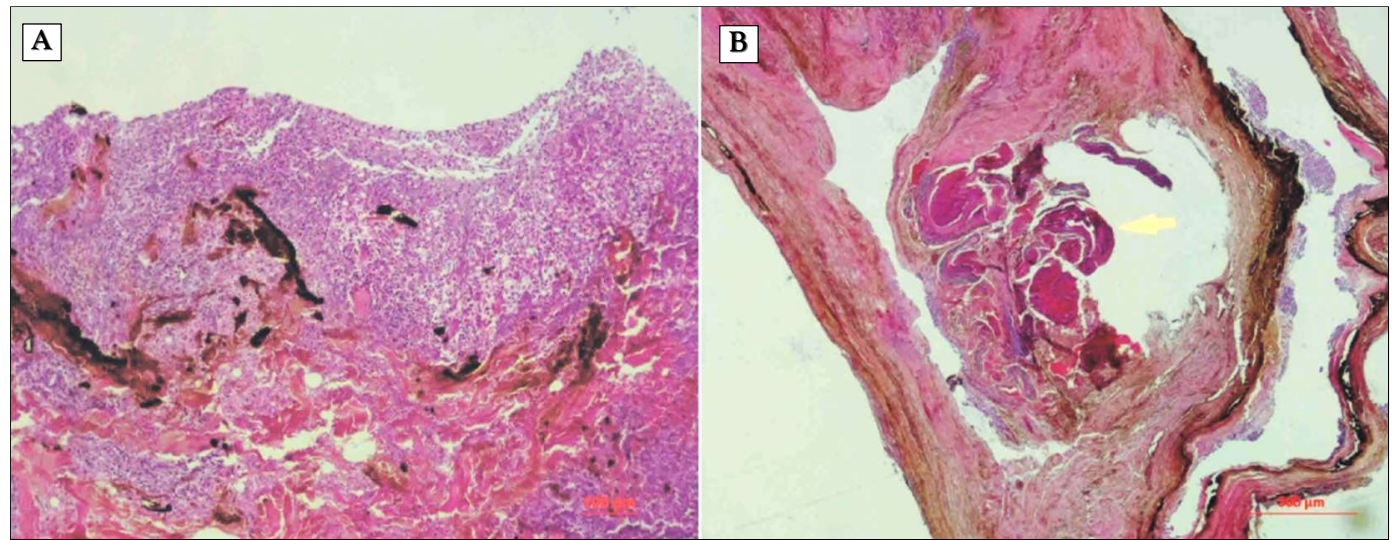

Figure 4. (A) Histological sections of specimens A. Neutrophil infiltration and nuclear debris and silver nitrate artefacts observed on the surface, eosinophilic necrotic tissue fragments, fibrocollagenous connective tissue, and sporadic mixed type inflammatory cells (hematoxylin and eosin staining; original magnification, $\times 100$ ). (B) Dense fibrous connective tissue, sporadic inflammatory cell collections, areas of degenerated regressive squamous cell in the center (arrow) (hematoxylin and eosin staining; original magnification, $\times 40$ ). 
treatment methods available for PSD, the selection of treatment method must be patientspecific $(8-11,15,16,19)$. Several studies reported that number of sinus pit orifices, distance of pit orifices from the midline, and the volume of the sinus tract were factors significantly impacting the choice of treatment method and treatment success $(20,21)$. In a study by Kaymakçıŏlu et al., increases in treatmentrelated complications as well as recurrence rates were reported in patients with four or more sinus orifices. In the same study, the volume of sinus cavity was found to be correlated with recurrence (21).

In the current study, while the cavity volume was not measured, the sinus tract length was evaluated. Our results indicated that increased tract length was associated with decreased success of the procedure and recurrence. The success rate in the current study was $91.1 \%$, whereas treatment success rates with phenol application were reported to range between $59 \%$ and $95 \%(9,22,23)$. Silver nitrate application was not recommended for patients with more than one tract, four or more sinus pit orifices, or sinus tract lengths of more than $1 \mathrm{~cm}$ in the current study. As even in patients with a single sinus tract in midline, alternative treatment options were likely recommended in the presence of 4 or more sinus pit orifices.

In 1982, Hoehn (16) used crystallized silver nitrate to treat PSD under local anesthesia at an outpatient clinical setting. In contrast to that study, silver nitrate sticks were used in the current study for efficient and easy delivery to the entire sinus tract. As described by Hoehn, removal of hair and lytic epithelial debris from the sinus orifice was necessary approximately two days after the procedure.

Histopathological examination of the tissue removed in the current study showed the presence of necrotic granulation tissue, neutrophil infiltration, with sporadic necrotic epithelium and fibrous connective tissue elements. These findings were in agreement with previous studies showing fibrotic dermal stroma surrounded by multi-layer squamous epithelium by histopathological examination of excised sinus tissue specimens (24).

Silver nitrate was not applied to patients with more than one sinus tract on USG due to the difficulty in application of silver nitrate stick to each sinus tract, and application of liquid silver nitrate might provide an advantage in these patients to increase success rate.

In the current study, the most frequently seen complication was abscess which developed in five patients. Hospitalization was not required for any of the patients, and all patients were treated with drainage under local anesthesia and antibiotics. The complication rate of minimally invasive methods such as phenol for PSD were reported as approximately $8.9 \%$ (9), with most frequently reported complications as skin erythema and necrosis. Other common complications include abscess formation and fatty tissue necrosis (25).

In the current study, $75 \%$ of the recurrent cases were those who developed abscesses. Furthermore, there was a significant correlation between abscess formation and recurrence. However, as this study included a small number of subjects, future studies with larger number of patients are necessary to confirm this finding. In addition, all recurrences developed within the first year. This result was in agreement with a previous study reporting that recurrence, which developed between 3 and 16 months after intervention of PSD, was more frequent in the first 12 -month period.

Limitations of the current study are the relatively small number of patients and the relatively short follow-up period. As this was a retrospective study, comparisons with other non-invasive methods or placebo treatments were not possible.

\section{Conclusion}

In this study, the patients tolerated silver nitrate application using a stick, which offered an opportunity for treatment of PSD at an outpatient setting with low rate of complications. Based on these findings, application of silver nitrate should be considered as an initial treatment option for suitable patients. 
Specifically, 90\% success rate in select cases provided strong evidence that this option should be offered to patients. Low morbidity and high healing rates support silver nitrate treatment as a suitable conservative treatment that should be considered for PSD in certain patients.

\section{Conflict of Interest}

The authors reported no conflicts of interest.

\section{Financial Support}

The authors received no financial support for the study.

Fundings: No

Ethical Approval: Retrospective study.

\section{References}

1. Quinodoz M, Grolleau JL, Chavoin JP, et al: Surgical treatment of pilonidal sinus disease by excision and skin flaps:The Toulouse experience. Eur J Surg 1999;165:1061-1065

2. Chintapatla S, Safarani N, Kumar S, et al: Sacrococcygeal pilonida sinus: historical review, pathological insight and surgical options. Tech Coloproctol 2003;7:3-8.

3. Tocchi A, Mazzoni G, Bononi M, et al: Outcome of chronic pilonida disease treatment after ambulatory plain midline excision and primary suture. Am J Surg 2008;196: 28-33.

4. Girgin M, Kanat BH, Ayten R, et al: Minimally invasive treatment of pilonidal disease: crystallized phenol and laser depilation.Int Surg. 2012;97:288-292.

5. Mentes 0, Oysul A, Harlak A, et al: Ultrasonography accurately evaluates the dimension and shape of the pilonidal sinus. Clinics (Sao Paulo). 2009;64:189-192.

6. Woo KY, Kwong EW, Jimenez C, Bishop R. Topical Agents and Dressings for Pilonidal Sinus Wound Healing by Secondary Intention: A Scoping Review. Surg Technol Int. 2015;26:57-63.

7. Lewis R, Whiting P, ter Riet G, O'Meara S, Glanville J. A rapid and systematic review of the clinical effectiveness and cost-effectiveness of debriding agents in treating surgical wounds healing by secondary intention. Health Technol Assess. 2001;5:1-131.

8. Kayaalp C, Tolan K. Crystallized or Liquid Phenol Application in Pilonidal Sinus Treatment. Indian J Surg. 2015;77:562-563

9. Kayaalp C, Aydin C. Review of phenol treatment in sacrococcygeal pilonidal disease. Tech Coloproctol 2009;13:189-193

10. Dogru O, Camci C, Aygen E, et al: Pilonidal sinus treated with crystallized phenol: An eight-year experience. Dis Colon Rectum 2004:47:1934-1938.

11. Kayaalp C, Olmez A, Aydin C, et al. Investigation of a one-time phenol application for pilonidal disease. Med Princ Pract. 2010:19:212-215

12. Oliveira RN, Rouzé R, Quilty B, Alves GG, Soares GD, Thiré RM, McGuinness GB. Mechanical properties and in vitro characterization of polyvinyl alcohol-nano-silver hydrogel wound dressings. Interface Focus. 2014 6;4:20130049.

13. Mulley G, Jenkins AT, Waterfield. Inactivation of the antibacterial and cytotoxic properties of silver ions by biologically relevant compounds. NR.PLoS One. 2014 11;9:e94409.

14. Attaallah W, Tuney D, Gulluoglu BM, et al. Should we consider topical silver nitrate irrigation as a definitive nonsurgical treatment for perianalfistula? Dis Colon Rectum. 2014;57:882-887

15. Korb JH. Infected pilonidal cysts; a simplified method of treatment. Mil Surg. 1951;108:29-34.

16. Hoehn GH. A simple solution to the therapeutic dilemma of pilonidal cysts. J Dermatol Surg Oncol. 1982;8:56-57.

17. Saylam B, Balli DN, Düzgün AP, et al. Which surgical procedure offers the best treatment for pilonidal disease? Langenbecks Arch Surg. 2011 Jun;396:651-658.

18. Nadworny PL, Wang J, Tredget EE, et al. Anti-inflammatory activity of nanocrystalline silver in a porcine contact dermatitis model. Nanomedicine. 2008:4:241-251.

19. Doll D, Matevossian E, Luedi MM, et al. Does Full Wound Rupture following Median Pilonidal Closure Alter Long-Term Recurrence Rate? Med Princ Pract. 2015;24:571-577.

20. Awad MM, Elbaset AA, Ebraheem S, et al. A scoring system as a method to evaluate pilonidal sinus disease to make an easy decision for its management. Indian J Plast Surg. 2009:42:43-48.

21. Kaymakcioglu N, Yagci G, Simsek A, et al. Treatment of pilonidal sinus by phenol application and factors affecting the recurrence. Tech Coloproctol. 2005;9:21-24

22. Schneider IH, Thaler K, Köcklerling HF. Treatment of pilonidal sinuses by Phenol solution injections. Int J Colorectal Dis 1994:9:200-202

23. Kelly SB, Graham WJ. Treatment of pilonidal sinus by Phenol solution injection. Ulster Med J 1989;58:56-59

24. Søndenaa K, Pollard ML. Histology of chronic pilonidal sinus. APMIS.1995;103: 267-272.

25. Sakçak I, Avsar FM, Cosgun E. Comparison of the application of low concentration and $80 \%$ phenol solution in pilonidal sinus disease. JRSM Short Rep. 2010 Jun 30:1:5. 